\title{
Heat Quality Enhancement and Carbon Dioxide Emissions Reduction from Coal Burning by Combining Low-Ranked Coal with Biomass Waste as A Clean Energy Solution to Achieve Energy Security in Indonesia
}

\author{
Ardian N. Baskoro ${ }^{1, *}$, Farhan H. Taskaya ${ }^{1}$, Ignatio Senoaji ${ }^{1}$, Robby Anggoro ${ }^{1}$ \\ ${ }^{1}$ Chemical Engineering Department, Faculty of Industrial Technology, Institut Teknologi Bandung, \\ Jalan Ganesa No. 10, Bandung 40132, Indonesia
}

Received 24 July 2021; Accepted 25 August 2021

Available online 31 August 2021

\begin{abstract}
Indonesia is the fifth largest coal producer in the world with coal reserves reaching 39.56 billion tonnes. Coal reserves of medium and high quality are expected to be exhausted in 2048, therefore it is necessary to utilize low-ranked coals. Low-ranked coals have a low heating value $(<5,100 \mathrm{kcal} / \mathrm{kg})$ and produce greater $\mathrm{CO}_{2} \mathrm{emissions}$ compared to medium and high rank coals. One method to increase heating value and reduce $\mathrm{CO}_{2}$ emissions from low-ranked coals is through the Utilization of hybrid coal. Hybrid coal is low quality coal combined with biomass waste and has undergone a pyrolysis process together. The mixing and co-pyrolysis of low-ranked coal with biomass waste such as rice husk, empty palm fruit bunches, and rubber wood with a ratio of 7:3 is known to be able to increase the final product calorific value by $31.10-44.12 \%$ and reduce non-neutral $\mathrm{CO}_{2}$ emissions by $15.56-21.31 \%$. The hybrid coal production process is highly prospective to be implemented in Indonesia, especially in Central Java, South Sumatra and South Kalimantan. The payback period from the hybrid coal industry with a production capacity range of 540 thousand to 4.5 million TPY can be achieved in 10-13 years with a net profit range of IDR 137 billion to IDR 493 billion per year and a net present value range of IDR 285 billion to IDR 1.1 trillion.
\end{abstract}

Keywords: biomass, coal, $\mathrm{CO}_{2}$ emission, co-pyrolysis, hybrid coal

\section{Introduction}

As one of the fastest developing country in the world, Indonesia has abundant population of approximately 267 million people. The population and subsequent GDP are also projected to be increasing throughout years. Consequently, this will lead to an increase in energy consumption and demand. Fact shows that through the years of 2012 up to 2017, there was a significant annual increase of $7 \%$ in Indonesia's electrical consumption. This projection urges the country to find the proper technology or innovation which utilizes country's abundant resources in order to fulfill the rapidly increasing energy demand, and furthermore achieving energy security.

\subsection{Current Indonesian Energy Condition and Its Security}

International Energy Agency (IEA) defined energy security as the prodigious, continuous and uninterrupted energy at affordable price and accessible state. Indonesia has an extensive number of diverse energy sources, hence being able to use and optimize all energy sources, including oil, natural gas, coal and renewables, is highly essential to achieve energy security. Analyzing the energy sector for the last few years, Indonesia has been fueled with various energy supplies which include the previously mentioned energy sources. Indonesia Energy Outlook 2019 has noted the total primary energy production of all these sources reaching up to 411.6 MTOE in 2018. It should be highlighted that

*Corresponding author

E-mail address: ardian.nugra@gmail.com 
Indonesia is currently known as the fourth largest producer of coal in the world with total coal export activity reaching around 261.4 MTOE. The Ministry of Energy and Mineral Resources has predicted that the energy demand will rise anually as the population for the upcoming years is projected to be increased. The energy demand will rise with an annual growth of $5.0 \%, 4.7 \%$ and $4.3 \%$ for three different scenarios, which are Business as Usual (BaU), Sustainable Development (SD) and Low Carbon (LC), respectively (Suharyati, Pambudi, Wibowo, \& Pratiwi, 2019). The growth of energy demand for 2020 up to 2050 period is shown in Figure 1.

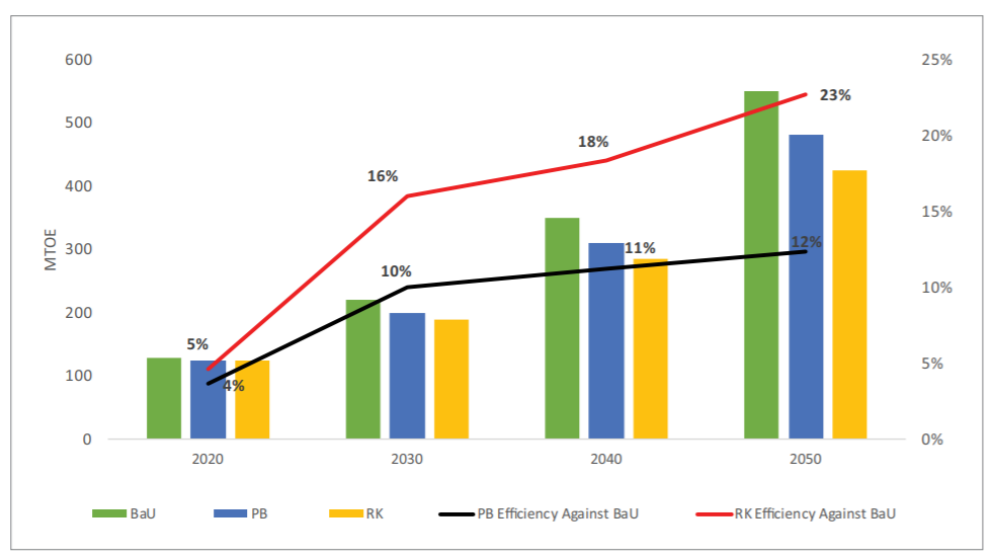

Figure 1. Comparison of Indonesia energy demand growth in three scenarios (Suharyati et al., 2019).

Based on Figure 1, the final energy demand of Indonesia in 2050 will reach 548.8 MTOE, 481.1 MTOE, and 424.4 MTOE, respectively (Suharyati et al., 2019). Nevertheless, the rising concern regarding global warming issues has led officials to shift the country energy demand into renewable resources. This affects the non-renewable sources of energy, such as coal especially, to be less favorable despite of its vast quantity.

\subsection{Coal Consumption and Coal Quality in Indonesia}

Coal is one of the largest energy sources in Indonesia. Indonesia's coal production were recorded at 560.7 million tonnes with coal reserves of 39.56 billion tonnes (Kementerian Energi dan Sumber Daya Mineral, 2020). More than $80 \%$ of domestic coal consumption is used for electricity generation (Direktorat Jenderal Mineral dan Batubara, 2020). Furthermore, coal consumption for electricity generation is expected to increase from 90 million tonnes in 2018 to 153 million tonnes in 2028 (PT. PLN (Persero), 2019).

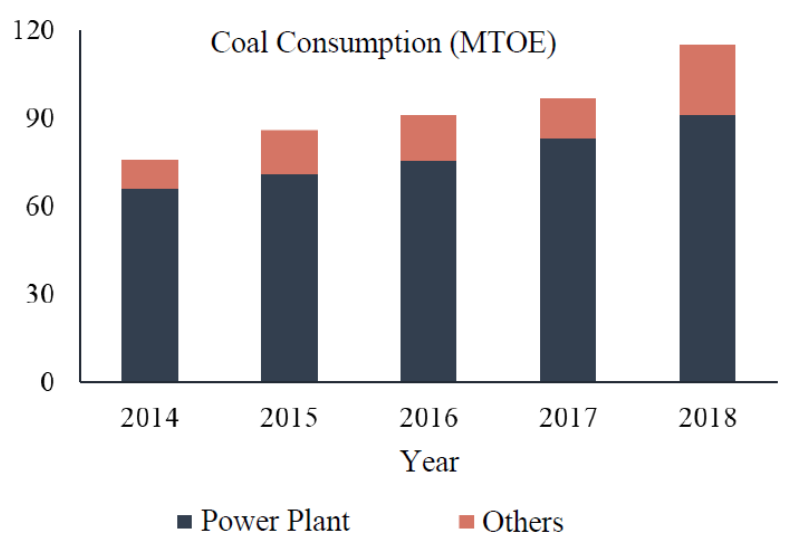

Figure 2. Coal domestic consumption (PT. PLN (Persero), 2019).

However, proven reserves of medium to high ranked coal are projected to be exhausted in 2038, and the total reserves of medium to high ranked coal will be exhausted in 2048 (BPPT, 2018). Since the better coal quality mostly used by metallurgy and cement production industry, powerplant with less 
grade specification requirement will use low quality coal $(<5,100 \mathrm{kcal} / \mathrm{kg})$ which still has several problems such as relatively high water content, low calorific value, low efficiency and high transportation costs (Song, Tahmasebi, \& Yu, 2014).

The amount of $\mathrm{CO}_{2}$ emissions produced by burning coal is very dependent on the grades of coal used. The higher the rank of coal, the lower the carbon emission for each unit of energy produced. Burning low quality coal will produce relatively higher $\mathrm{CO}_{2}$ emissions for each unit of energy it produces. $\mathrm{CO}_{2}$ is a greenhouse gas (GHG) that causes global warming. The average emission factor from burning coal is $99,718 \mathrm{~kg} \mathrm{CO}_{2} / \mathrm{TJ}$ (Kementerian Energi dan Sumber Daya Mineral, 2017). With a total coal-fired power plant capacity of $25.7 \mathrm{GW}, \mathrm{CO}_{2}$ emissions due to burning coal to produce electricity reached around 68 GTonne/year. On the other hand, Indonesia has committed to reducing $\mathrm{CO}_{2}$ emissions as much as $26 \%$ by 2020 and $29 \%$ by 2030 as stated in Indonesia's first Nationally Determined Contribution (NDC) in 2016. Therefore, it is extremely crucial to discover a cleaner and more efficient technology to utilize the abundance of coal as a way to achieve Indonesia's energy security. Figure 3 shows the magnitude of the emission factor by each type of coal.

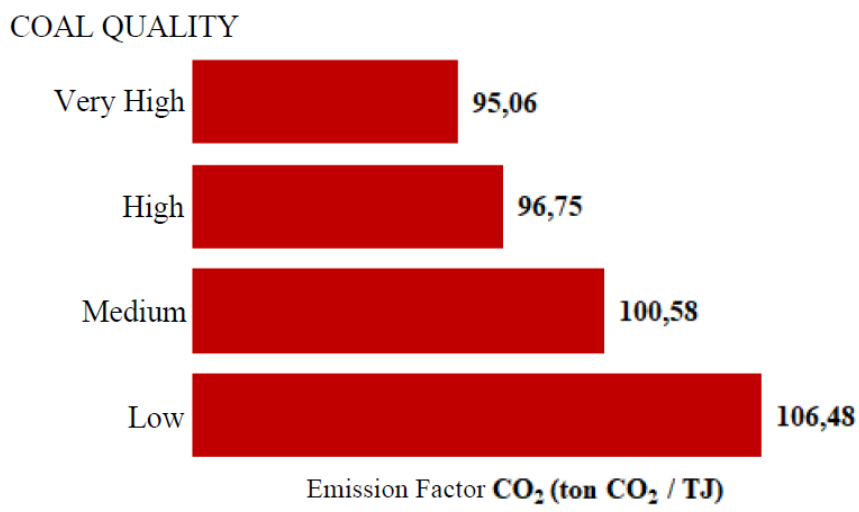

Figure 3. Comparison of coal emission factor (Kementerian Energi dan Sumber Daya Mineral, 2016).

The average coal combustion will produce $0.36 \mathrm{~kg}$ of $\mathrm{CO}_{2}$ for every $\mathrm{kWh}$ of electricity generated. To date, 59.91\% of Indonesia's electricity generation is still dependent on coal (PT. PLN (Persero), 2018). The International Renewable Energy Agency (IRENA) noted that the total capacity of coal-fired steam power plants reached $25.7 \mathrm{GW}$. With this total capacity, the $\mathrm{CO}_{2}$ emissions produced by Indonesia are estimated to reach 68.54 GTonnes every year just to generate national electricity.

\subsection{Potential Indonesian Biomass Sources}

Besides coal, another solid fuel that can also be used to produce energy is biomass. Biomass is a new and renewable energy source, whose sources can be categorized into agricultural waste, forestry waste, urban waste, oil-producing plants and biological waste (Basu, 2013). Burning biomass from these sources produces neutral $\mathrm{CO}_{2}$ which does not have any impact on the accumulation of $\mathrm{CO}_{2}$ in the atmosphere. In addition, $\mathrm{SO}_{\mathrm{x}}$ and $\mathrm{NO}_{\mathrm{x}}$ emissions produced from biomass are also small so they do not pollute the atmosphere.

Indonesia has abundant biomass resources with a total potential of $32.6 \mathrm{GW}$. The potential of various kinds of biomass is shown in Figure 4. According to the Director General of New, Renewable Energy and Energy Conservation, Ministry of Energy and Mineral Resources, the total general potential of biomass waste into electricity in Indonesia is 32,654 MWe with rice having the second largest potential of 9,808 MWe after oil palm with a potential of 12,654 MWe (Ditjen EBTKE, 2016). Although the potential of biomass in Indonesia is extensive, biomass has a much lower heat density compared to coal. Table 1 shows the calorific value of lignite coal and several types of biomass. The low heat density of biomass causes the need for more biomass to produce the same energy as coal. This will cause problems, especially for its transportation. 
Table 1. Calorific value of lignite coal and biomass waste (Sasongko, Wulandari, Rubani, \& Rusydiansyah, 2017).

\begin{tabular}{lc}
\hline \multicolumn{1}{c}{ Material } & Calorific Value $(\mathrm{kcal} / \mathrm{kg})$ \\
\hline Rice Husk & 2.73 \\
Empty Fruit Bunch & 3.93 \\
Rubber Wood & 4.06 \\
Lignite Coal & 5.03 \\
\hline
\end{tabular}

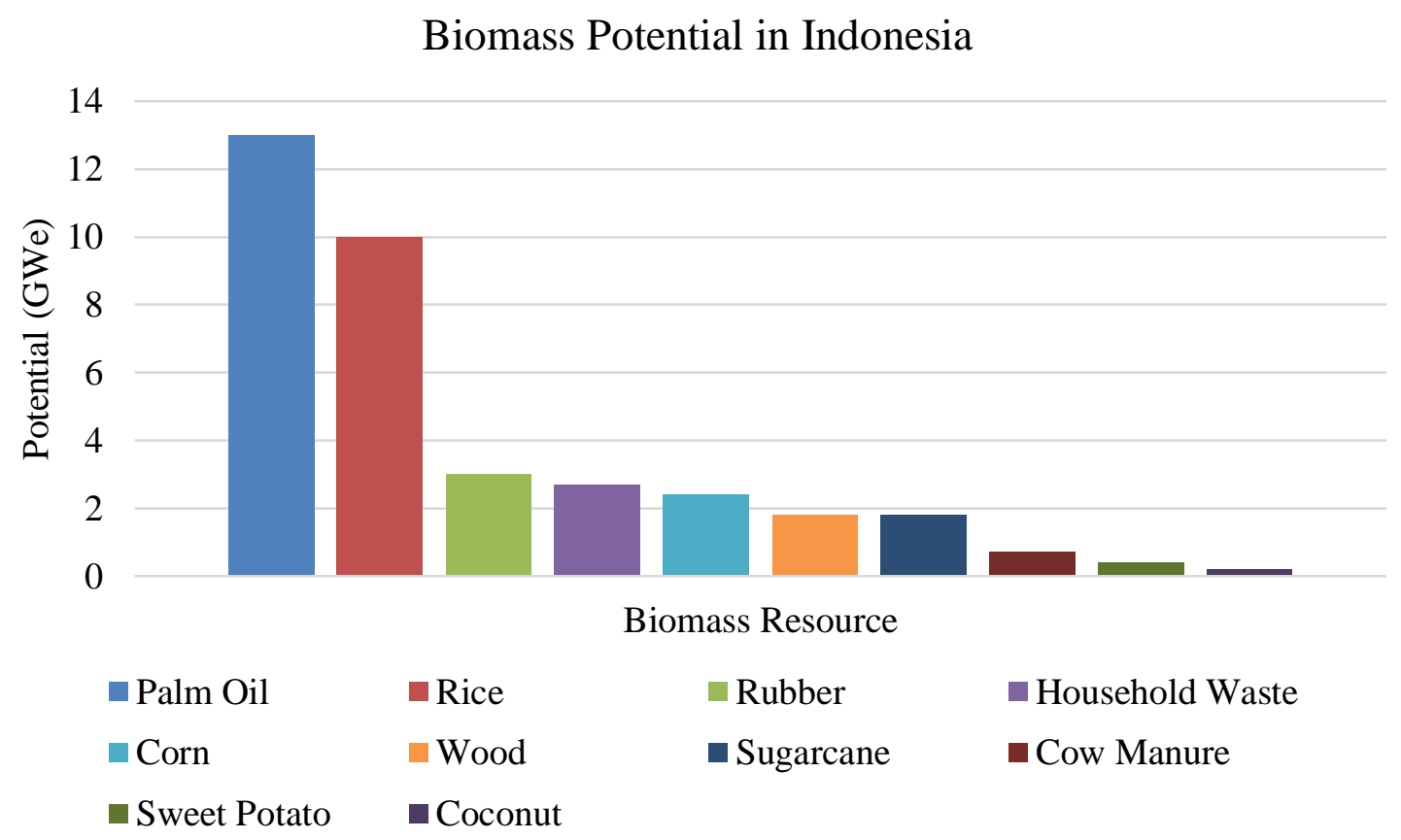

Figure 4. Comparison of biomass potential in Indonesia (Gielen, Saygin, \& Rigter, 2017; Tun, Juchelkova, Win, Thu, \& Puchor, 2019).

\subsection{Objective of The Study}

The concern of Indonesian energy security can be answered through the utilization of Indonesia's current big coal reserves. Unfortunately, various new policies and regulations that are implemented and signed revolving ways to reduce global warming and $\mathrm{CO}_{2}$ emission, and thus making coal uncosiderably to be a non-clean technology. In addition, the quality of the produced coal is considered to be lowranked coal. Therefore, in order to maximize the utilization of coal potential in Indonesia, a new innovation and technology is required to enhance the heat quality of the low-ranked coal and produce lower $\mathrm{CO}_{2}$ emission. This can only be achieved by involving biomass waste potential, which also abundant in Indonesia, into the coal enhancement effort. The quality of Indonesia's low-ranked coal is upgraded to the equivalent of higher rank coal by mixing waste biomass to form hybrid coal, followed by co-pyrolysis. In hybrid coal co-pyrolysis, the type of coal and biomass affect the energy gain of the co-pyrolysis product and it is necessary to know the relationship (Quan \& Gao, 2016). Several study and work related to coal and various biomass waste type co-pyrolysis have shown the same tendencies on increasing hybrid coal calorific value and decreasing $\mathrm{CO}_{2}$ emission. The study shows that hybrid coal have lower $\mathrm{H} / \mathrm{C}$ ratio from coal, thus inferred that the ignition temperature of hybrid coal is lower compared to its raw coal and biomass which implicates on reducing the initial energy required to burn hybrid coal (Quan \& Gao, 2016; Sasongko et al., 2017).

The objective of this study is to present a product innovation of hybrid coal by co-pyrolysis process of low-ranked coal and biomass waste mixture. This will include the product quality and feasibility analysis and examination of hybrid coal to produce a higher heat quality of coal with lower $\mathrm{CO}_{2}$ emission. Moreover, considering the potential of biomass in Indonesia, this study also analyzes the 
feasibility of different biomass waste implementation into the hybrid coal production. With the appropriate technology, coal and biomass waste can be combined as hybrid coal and thus becoming realiable and cleaner resource for Indonesia to achieve energy security. This analysis is achieved through a series of literature review and lab scale experiment.

\section{Coal and Biomass Utilization Technology}

\subsection{Co-firing Process Technology}

One of the biomass utilization processes that have been developed is the burning of biomass altogether with coal which is known as the co-firing process. In this process, biomass is directly burned together with coal without going through any series of prior treatments. A literature stated that the use of biomass for pulverized firing is still very limited, especially in terms of biomass particle size and water content. As a result, the biomass that can be used for this method is only the one that has been reduced in size into powder form, for example sawdust. The same literature also indicates that direct co-firing of biomass with coal cannot be carried out in fixed bed furnace (Roni et al., 2017). Most of the current existing coal powerplant technology are facing technical issues regarding coal burning. The presence of biomass without additional pre-treatment will have high alkali and moisture content. This will worsen the current technical issue and makes the combustion less effective. Therefore, the co-firing process of coal with biomass is still considered to be less efficient, especially in Indonesia.

\subsection{Co-pyrolysis Process Technology}

Another method for harnessing the energy and carbon neutral nature of biomass is through the copyrolysis process. Co-pyrolysis is the process of heating coal with biomass altogether without the presence of oxygen. Heating causes reduction in water content and volatile hydrocarbon compounds contained in coal. Subsequently, this leads to an increase in the calorific value of the mixture. Heating also causes thermal decomposition of the chemical structure of biomass so that biomass becomes less susceptible to decay. The mechanism that occurs in the co-pyrolysis process can be divided into 5 regimes based on the temperature (Basu, 2013):

- Regime A is a non-reactive drying regime in which a reduction in water content occurs without being followed by a change in chemical composition that takes place in the temperature range of $50-120{ }^{\circ} \mathrm{C}$.

- Regime $\mathrm{B}$ is a regime in which lignin softens into an adhesive material which takes place in the temperature range of $120-150{ }^{\circ} \mathrm{C}$.

- Regime $\mathrm{C}$ is a reactive drying regime in which the breaking of the $\mathrm{C}-\mathrm{H}$ bonds and the depolymerization of hemicellulose produce a condensed short polymer which takes place in the temperature range of $150-200{ }^{\circ} \mathrm{C}$.

- Regime D is a hemicellulosic torefaction regime, characterized by devolatilization and carbonization of solids due to the breaking of intermolecular and intramolecular hydrogen bonds, $\mathrm{C}-\mathrm{C}$, and $\mathrm{C}-\mathrm{O}$ to form tar and gases, which take places in the temperature range of $200-250{ }^{\circ} \mathrm{C}$.

- Regime $\mathrm{E}$ is a regime in which the decomposition of hemicellulose continues, accompanied by devolatilitation and carbonization of cellulose and lignin which takes place in the temperature range of $250-300{ }^{\circ} \mathrm{C}$. The cell structure of the biomass has been completely destroyed to produce a brittle, hydrophobic solid product. 


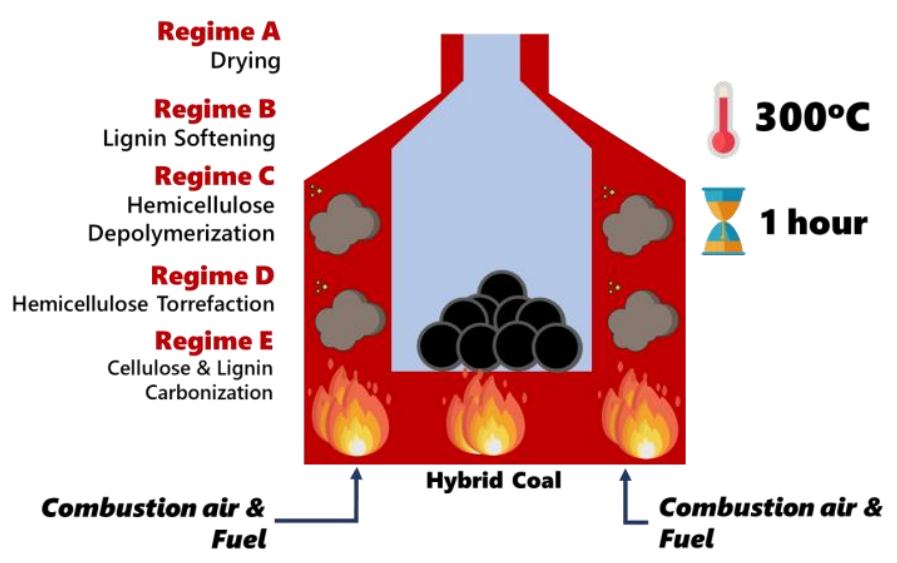

Figure 5. Illustration of regimes during co-pyrolysis process.

The co-pyrolysis product of coal and biomass will produce a new solid fuel called hybrid coal. Combining biomass with coal can reduce the non-neutral $\mathrm{CO}_{2}$ emissions originally produced by pure coal burning. Then it is followed by a co-pyrolysis process to increase the calorific value of the biomass. A research shows that co-pyrolysis of coal and biomass mixture at a ratio of 7:3 is able to increase its heating value up to $31 \%$ and reduce $\mathrm{CO}_{2}$ emissions up to $14.3 \%$ making it advantageous to be implemented (Sasongko et al., 2017). In addition, the relatively mild process condition of co-pyrolysis process makes it generally feasible to be up-scaled to the industrial production. Nevertheless, this process requires additional pre-treatment stage which makes it relatively costly in CAPEX.

\section{Methodology}

\subsection{Materials}

The co-pyrolysis process in the production of hybrid coal requires two main raw materials, which are low-ranked coal and biomass. There is also supporting material, which is molasses, as binding agent to tighten the coal and the biomass during the co-pyrolysis process. In addition, water is also used to liquefy the molasses. The complete equipment and materials used during the experiment are presented in Table 2.

Table 2. Equipment and materials used during the laboratory scale experiment.

\begin{tabular}{ll}
\hline \multicolumn{1}{c}{ Equipment } & \multicolumn{1}{c}{ Materials } \\
\hline Furnace (co-pyrolysis reactor) & Lignite type coal \\
Oven/ Dryer & Biomass Waste: \\
& Rice Husk \\
& Rubber Wood \\
& Empty Fruit Bunch \\
& Molasses \\
& Water \\
& Nitrogen $\left(\mathrm{N}_{2}\right)$ \\
\hline
\end{tabular}

This research was aimed to compare the quality of mixture of lignite type coal with 3 different types of biomass waste, namely rice husk, rubber wood and palm oil empty fruit bunch. The mixture has the 7:3 ratio of coal to biomass. On the laboratory scale experiment, the co-pyrolysis process takes place in a furnace which further called as the co-pyrolysis reactor. The reactor scheme is depicted in Figure 6. 


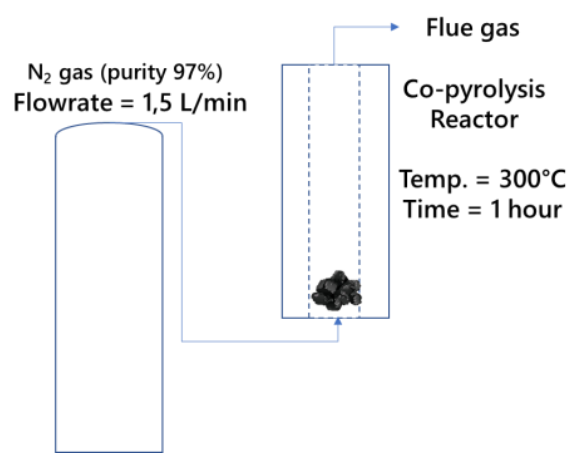

Figure 6. Co-pyrolysis reactor configuration on a laboratory scale experiment.

\subsection{Methods}

The hybrid coal production process consists of 3 main stages, namely size reduction, mixing and molding, and co-pyrolysis. The stages in the production of hybrid coal are shown in Figure 7.

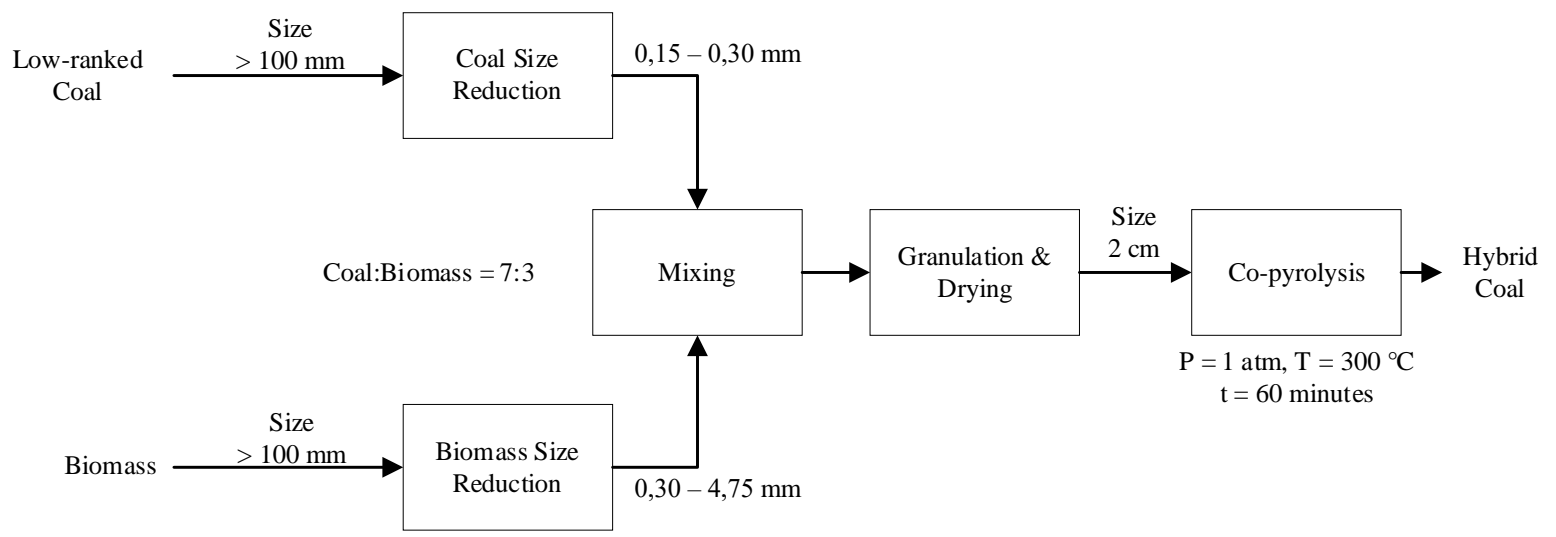

Figure 7. Hybrid coal production stages on a laboratory scale experiment.

Firstly, coal is reduced in size to $0.15-0.30 \mathrm{~mm}$ diameter and biomass is reduced to $0.30-4.75 \mathrm{~mm}$ diameter. The size reduction stage aims to facilitate the homogeneous mixing process of coal and biomass. Size reduction was carried out using a blender and a ball mill. After reaching the desired size, coal and biomass are mixed with a mass ratio of 7:3 (referring to the optimum ratio used by Sasongko et al. in their research) until they are homogeneous. An adhesive agent in the form of molasses is added to the coal-biomass mixture to support the granulation (molding) process. At this stage, the mixture of coal, biomass and molasses is granulated to gain sphere pellets having approximately $2 \mathrm{~cm}$ in diameter. Then, the pellets are dried in an oven at $100{ }^{\circ} \mathrm{C}$ for 24 hours to reduce the moisture content and compact the pellet structure, hence reducing the heating load of the following co-pyrolysis process. The drying process produces solid coal-biomass mixture pellets which sticks firmly inside. After drying, the pellets are put into the co-pyrolysis reactor. The co-pyrolysis process was run at $300{ }^{\circ} \mathrm{C}$ for 1 hour. During copyrolysis process, $\mathrm{N}_{2}$ gas is passed through the reactor as an inert gas to reduce the $\mathrm{O}_{2}$ concentration in the reactor, thus preventing combustion. Combustion is undesirable since it will consume the fixed carbon content in the pellets. The co-pyrolysis process produces hybrid coal as the desired product. The hybrid coal is then cooled and stored for proximate, ultimate and calorific value analysis.

The economic evaluation was conducted using three economic parameters namely Payback Period, NPV and IRR which calculated based on following terminology (Turton, Bailie, Whiting, Shaeiwitz, \& Bhattacharyya, 2012). It requires graphical analysis of the cashflow diagram in order to earn the values. - Payback Period: Time required, after start-up, to recover the fixed capital investment for the project.

- NPV: Cumulative discounted cash position at the end of the project.

- IRR: Interest or discount rate for which the net present value (NPV) of the project is equal to zero. 


\section{Hybrid Coal Quality Analysis}

Analysis were carried out on hybrid coal products with rubber wood and oil palm empty fruit bunch. Meanwhile, the analysis on hybrid coal product with rice husk refer to data obtained from the literature (Sasongko et al., 2017). The overall analysis result for all hybrid coal products are shown in Table 3.

Table 3. Hybrid coal quality analysis result.

\begin{tabular}{|c|c|c|c|c|c|c|c|c|c|c|c|}
\hline \multirow[b]{2}{*}{ Materials } & \multicolumn{4}{|c|}{ Proximate Analysis (\%-wt dry basis) } & \multicolumn{6}{|c|}{ Ultimate Analysis (\%-wt dry basis) } & \multirow{2}{*}{$\begin{array}{c}\mathrm{GCV} \\
(\mathrm{kcal} / \\
\mathrm{kg})\end{array}$} \\
\hline & Ash & $\begin{array}{l}\text { Fixed } \\
\text { Carbon }\end{array}$ & $\begin{array}{l}\text { Volatile } \\
\text { Matter }\end{array}$ & Moisture & $\mathrm{C}$ & $\mathrm{H}$ & $\mathrm{O}$ & $\mathrm{N}$ & $\mathrm{S}$ & Other & \\
\hline \multicolumn{12}{|c|}{ Rice Husk (Sasongko et al., 2017) } \\
\hline Coal & 2.07 & 37.71 & 42.20 & 18.02 & 54.81 & 5.46 & 36.87 & 0.71 & 0.08 & 2.07 & 5,027 \\
\hline Biomass & 32.21 & 11.50 & 47.41 & 8.88 & 28.65 & 4.60 & 33.67 & 0.77 & 0.10 & 32.21 & 2,726 \\
\hline Hybrid & 11.89 & 51.04 & 34.00 & 3.07 & 65.06 & 3.73 & 18.26 & 0.86 & 0.20 & 11.89 & 5,689 \\
\hline \multicolumn{12}{|c|}{ Empty Fruit Bunch } \\
\hline Coal & 18.07 & 29.84 & 34.35 & 17.74 & 46.08 & 5.01 & 29.83 & 0.58 & 0.43 & 18.07 & 4,183 \\
\hline Biomass & 8.10 & 17.02 & 65.16 & 9.72 & 41.70 & 6.06 & 43.31 & 0.70 & 0.13 & 8.10 & 3,925 \\
\hline Hybrid & 12.53 & 45.80 & 40.75 & 0.92 & 63.30 & 4.04 & 18.14 & 1.15 & 0.84 & 12.53 & 5,918 \\
\hline \multicolumn{12}{|c|}{ Rubber Wood } \\
\hline Coal & 18.07 & 29.84 & 34.35 & 17.74 & 46.08 & 5.01 & 29.83 & 0.58 & 0.43 & 18.07 & 4,183 \\
\hline Biomass & 1.70 & 16.31 & 70.57 & 11.42 & 44.27 & 6.37 & 47.47 & 0.07 & 0.12 & 1.70 & 4,058 \\
\hline Hybrid & 11.22 & 47.67 & 39.71 & 1.40 & 62.22 & 4.13 & 20.65 & 1.07 & 0.71 & 11.22 & 5,716 \\
\hline
\end{tabular}

According to the analysis result, it is known that there is an increase in calorific value which is initially in the range of low-ranked coal/ lignite $(<5,100 \mathrm{kcal} / \mathrm{kg})$ to medium-ranked coal/ subbituminous $(5,100$ $6,100 \mathrm{kcal} / \mathrm{kg}$ ). This shows that the co-pyrolysis process is the effective method to increase the heating value of coal and biomass so that it can be used as a more efficient fuel. The increase in heating value occurs due to the evaporation of water content and volatile compounds in coal and biomass that happened during the co-pyrolysis process. The presence of water in coal causes the combustion heat absorption to raise the temperature and evaporate the water which affects the remaining combustion heat to be utilized. In addition, the reduction in volatile compounds which have a lower heating value than fixed carbon also causes the increase in the heating value of hybrid coal. The combustion of volatile compounds will cause fire, while combustion of fixed carbon will produce flaming embers.

Biomass has higher content of volatile compounds than coal. As a result, burning biomass will firstly produces fire prior to flaming embers formation. If this is applied to a furnace, the burning of biomass will leave unburn carbon in the form of a black stain on the furnace wall. This is definitely undesirable for industrial coal burning furnaces in power plants, especially those that utilize Pulverized Coal Combustion furnaces. The application of co-pyrolysis process is able to reduce the volatile matters in biomass, making the biomass suitable and better to be applied to the furnace.

Based on the results of this research, the hybrid coal produced using the process of co-pyrolysis is able to increase the heating value and reduce the total $\mathrm{CO}_{2}$ emissions from original coal burning. Table 4 shows both the increase and decrease percentage of the material calorific value and $\mathrm{CO}_{2}$ emission, respectively.

Table 4. The increase in calorific value and decrease in $\mathrm{CO}_{2}$ emission of hybrid coal.

\begin{tabular}{lcc}
\hline $\begin{array}{c}\text { Biomass Waste Constituent of } \\
\text { the Hybrid Coal }\end{array}$ & Calorific Value Increase (\%) & $\mathrm{CO}_{2}$ Emission Decrease (\%) \\
\hline Rice Husk & 31.10 & 15.56 \\
Empty Fruit Bunch & 44.12 & 18.40 \\
Rubber Wood & 37.87 & 21.31 \\
\hline
\end{tabular}


The calorific value is the energy released in the form of heat per unit mass of solid product when the solid undergoes complete combustion. The calorific value of coal raw materials, biomass raw materials, hybrid coal products, and standard types of coal in the form of GCV are shown in Table 3. According to Table 4, there is an increase in hybrid coal calorific value with the percentage range of $31.10-44.12 \%$ compared to its coal raw material constituent. This increase occurs due to reduction of water content and volatile compounds in coal and biomass mixtures, followed by an increase in fixed carbon content during co-pyrolysis. The carbon content is the main source of heat energy released when burning a fuel.

In addition, non-neutral $\mathrm{CO}_{2}$ reduction occurred as shown in Table 4. Calculations were carried out on the basis of the amount of energy generated from the complete combustion of a hybrid coal sample to reach $100 \mathrm{MW}$. The carbon neutral composition of the biomass in the hybrid coal product is assumed to follow the theoretical calculation results according to the biomass raw material yield, while the nonneutral carbon composition of the coal in the hybrid coal product is the residual value. This assumption is used because of the synergistic effect on hybrid coal recovery that occurs due to changes in the thermal decomposition of coal components. Hence, the theoretical calculations according to coal raw material yield cannot be used. The reduction in $\mathrm{CO}_{2}$ emissions of hybrid coal varies and is in a narrow range of $15.56-21.31 \%$. These results indicate that hybrid coal is more environmentally friendly than the original coal when used as fuel in a power plant. The high non-neutral $\mathrm{CO}_{2}$ emission reduction value from hybrid coal occurs due to the high calorific value of hybrid coal and the low composition of nonneutral $\mathrm{C}$ elements in the product. The high calorific value causes the required mass amount of hybrid coal to be reduced, while the low elemental composition of non-neutral $\mathrm{C}$ causes the emission of nonneutral $\mathrm{CO}_{2}$ to also be low.

\section{Feasibility Study}

Hybrid coal is a very prospective source of energy since it has the ability to increase the calorific value of biomass and low-ranked coal as well as reducing non-neutral $\mathrm{CO}_{2}$ emissions. As a country rich in biomass sources and abundant coal reserves, Indonesia has great potential to produce hybrid coal for commercial purpose. Hybrid coal production in Indonesia on an industrial scale can follow the process configuration as shown in Figure 6.

\subsection{Material \& Plant Location Study}

There are several prospective locations to build hybrid coal plants in Indonesia. The locations are determined based on the distance closeness criterion which cover all the required material sources for hybrid coal production such as biomass, coal mines, water sources, and most importantly the market target which is steam power plant with large electricity capacity. It is also based on the most optimum biomass potential in the area and the diversification of the existing biomass for each area. The geopotential study gives three most suitable areas for the hybrid coal plant location, namely South Sumatra, South Kalimantan, and Central Java. The corresponding biomass potential is presented in Table 5.

Table 5. Biomass potential in Indonesia (Kementerian Pertanian, 2018).

\begin{tabular}{|c|c|c|c|}
\hline \multirow{2}{*}{ Biomass } & \multicolumn{3}{|c|}{ Production (as per 2018) } \\
\hline & Total & Region with & $\mathrm{n}$ production \\
\hline Rice & $81.15 \mathrm{M}$ tonnes & Central Java & $11.40 \mathrm{M}$ tonnes \\
\hline Palm Oil & 37.80 $\mathrm{M}$ tonnes & South Kalimantan & $1.36 \mathrm{M}$ tonnes \\
\hline Rubber Wood & $3.63 \mathrm{M}$ tonnes & South Sumatera & 997,682 tonnes \\
\hline
\end{tabular}

Based on 2018 agricultural statistics, $21 \%$ of palm oil biomass is the empty fruit bunch waste, $20 \%$ of rice is the rice husk waste and $18 \%$ of rubber production is the rubber wood waste. These biomass wastes are the ones that is underutilized in Indonesia (Kementerian Pertanian, 2018). The detailed results of the location and raw material study of the hybrid coal plant are presented in Table 6. 
Table 6. Raw material and market target location of hybrid coal plant.

\begin{tabular}{lccccc}
\hline \multirow{2}{*}{ Plant Area } & \multicolumn{3}{c}{ Raw Material Source } & \multicolumn{2}{c}{ Market Target } \\
\cline { 2 - 6 } & Coal & Biomass Waste & Water & Power Plant & Capacity \\
\hline Central Java & PT AGM & Spread* & Java Sea & Tanjung Jati B & $4 \times 660 \mathrm{MW}$ \\
South Kalimantan & PT AGM & CPO Plant & Barito River & Asam-asam & $2 \times 65 \mathrm{MW}$ \\
South Sumatera & PT BA & PTPN 7 & Enim River & Sumsel 8 & $2 \times 620 \mathrm{MW}$ \\
\hline
\end{tabular}

*The rice husk sources are spread all around Central Java, it is recommended to built approximately 3 warehouses collection point throughout Central Java.

Based on Table 5 and 6, the three area has met several predetermined criteria, hence they are eligible to be places for the hybrid coal production plant. Coal and biomass transportation can be carried out using trucks and barges. Meanwhile, biomass waste transportation system may differ for each type. The source of biomass waste in Central Java is collected by setting up three warehouses in several areas across Central Java to collect rice husk from multiple location nearby, then it is transported to the location of a hybrid coal plant in Jepara. In South Sumatra, rubber wood is directly transported from PTPN 7 rubber wood plantations. For South Kalimantan area, empty fruit bunches are taken from CPO mills located nearby the area.

\subsection{Economic Study}

An economic study was conducted to see the financial feasibility of the hybrid coal plant. The assumptions used in this economic study are as follows.

1. Hybrid coal production capacity is in accordance with the biomass waste availability, the coal to biomass ratio applied is 7:3.

2. The plant life from the beginning of the project until the end of operation is 22 years.

3. The average interest rate for bank loans for industry is $9.91 \%$.

4. The area of land required is 40 hectares with the approximation based on the required space for process equipments, material storages, utilities, waste treatment, green area and future expansion.

5. The dollar exchange rate is IDR $14,050,00$.

6. Calculation of coal price refers to the reference coal price in September 2019. The selling price has an additional valuation due to the environmentally friendly offered benefit.

7. Employee salary is 3 times the Provincial Minimum Wage, with a total employee consisting of 4 shifts and 3 teams.

8. The electricity is generated from PLN, while the water used comes from its own water source.

9. The biomass waste prices are based on actual survey to several representative farmers, and it has been set above the average price in order to improve farmers economical well-being.

The price of low-ranked coal (lignite) is obtained from the Reference Coal Price with a value of USD 40-50 per tonne, while the biomass price is presented in Table 7. Meanwhile, the plant capacity and demand for low ranked coal and biomass waste for the hybrid coal plant is presented in Table 8 .

Table 7. The used biomass waste price.

\begin{tabular}{lc}
\hline \multicolumn{1}{c}{ Biomass Waste Type } & Price per Tonne \\
\hline Rice Husk & IDR $100,000,00$ \\
Empty Fruit Bunch & IDR $110,000,00$ \\
Rubber Wood & IDR $20,000,00$ \\
\hline
\end{tabular}

Table 8. Capacity and demand for coal \& biomass in hybrid coal plants.

\begin{tabular}{lccc}
\hline \multirow{2}{*}{ Plant Area } & \multirow{2}{*}{ Plant Capacity (TPY) } & \multicolumn{2}{c}{ Raw Material Demand (TPY) } \\
\cline { 3 - 4 } & & Low Ranked Coal & Biomass Waste \\
\hline Central Java & $4,498,894$ & $4,485,667$ & $1,922,000$ \\
South Kalimantan & $1,078,936$ & $1,078,000$ & 462,000 \\
South Sumatera & 540,022 & 598,200 & 179,460 \\
\hline
\end{tabular}


Based on Table 8, hybrid coal plant which requires the largest coal demand are located in the Central Java area. This is due to the fact that rice husk biomass has the largest production in Indonesia, especially in Central Java, so the need for coal is also the largest in the area. In addition, the price of equipment (bare module cost) for the hybrid coal plant is mostly reviewed from several sources, such as simulations using ASPEN Process Economic Analyzer V10 and CapCost calculations. Furthermore, the cost calculation and economical calculations are based on Turton's textbook (Turton et al., 2012). The supply chain general schemes for all three designated locations are shown in Figure 8 to Figure 10.

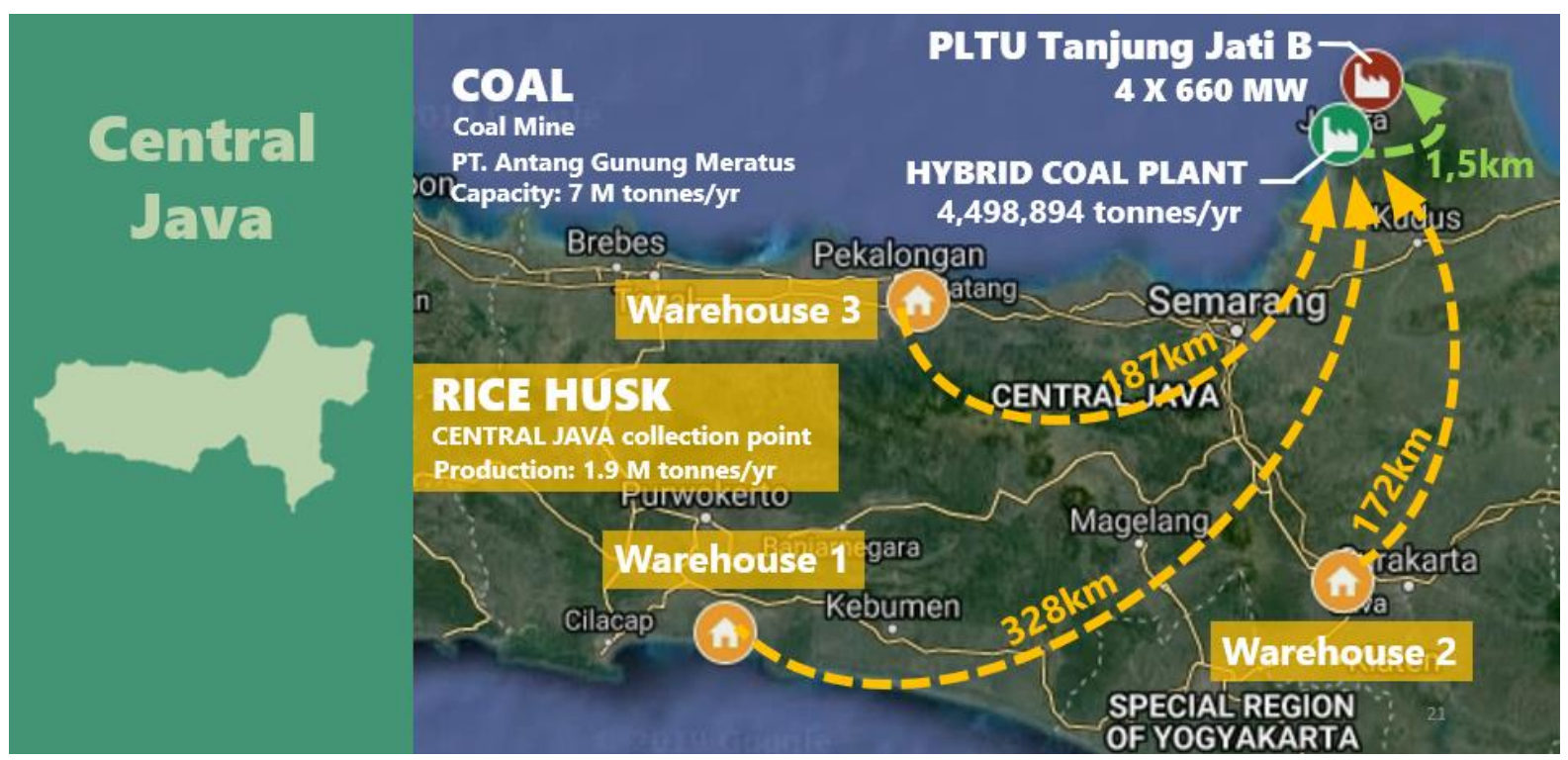

Figure 8. Hybrid coal plant supply chain and market target scheme in Central Java.

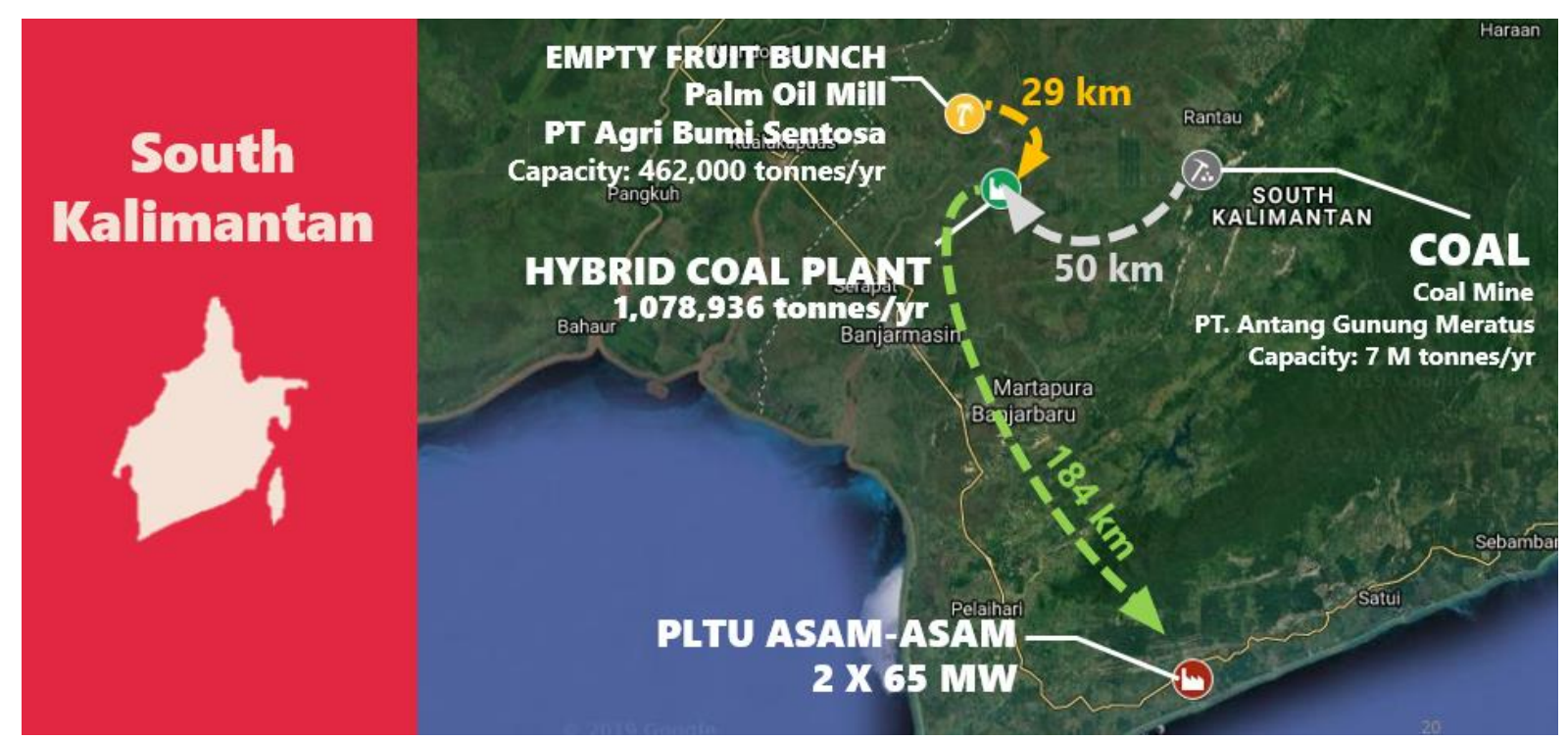

Figure 9. Hybrid coal plant supply chain and market target scheme in South Kalimantan. 


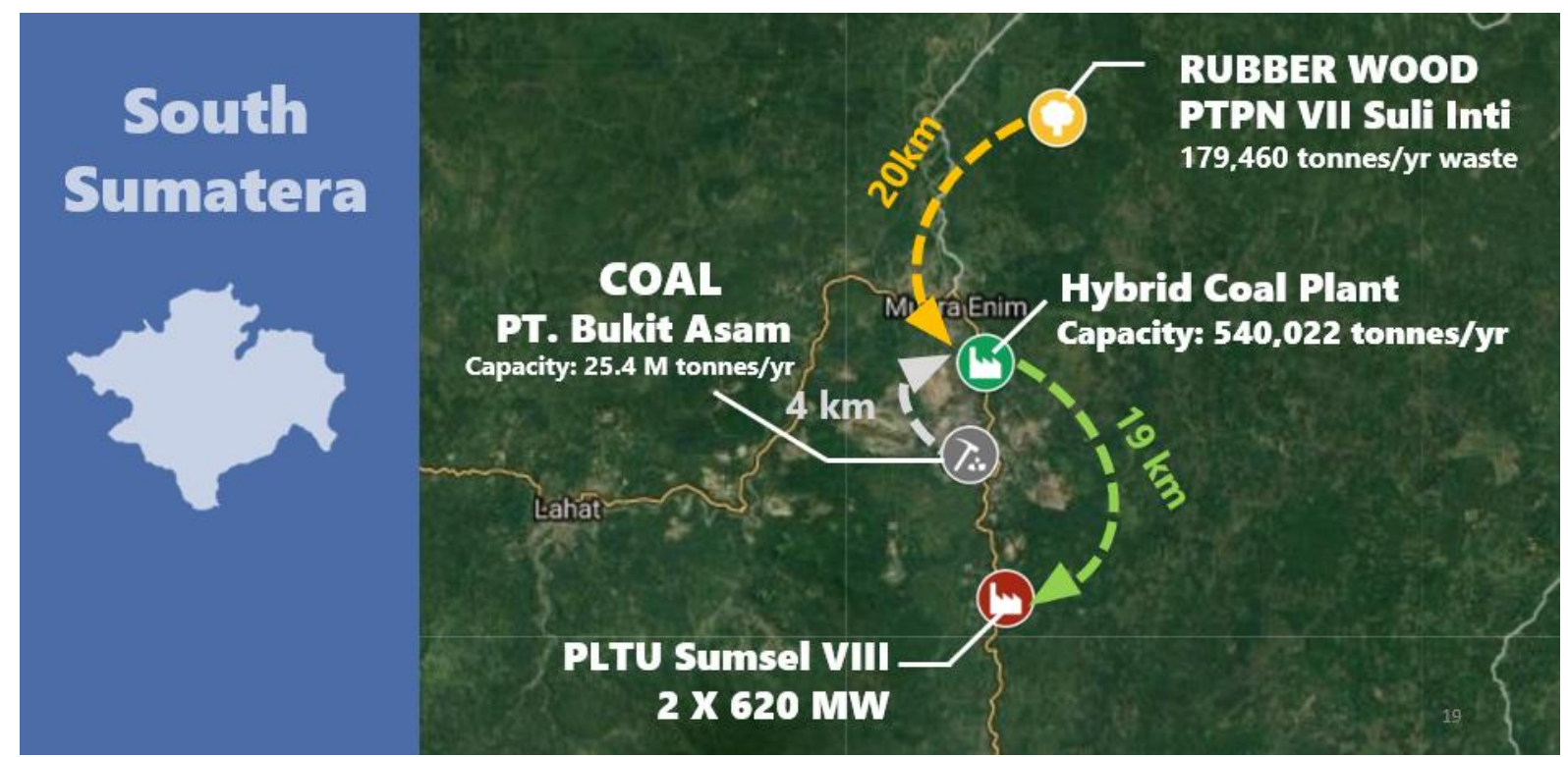

Figure 10. Hybrid coal plant supply chain and market target scheme in South Sumatera.

The basis for consideration of the selling price of hybrid coal product is based on the carbon tax and carbon regulations that will be applied in near future starting at USD 10/tonne $\mathrm{CO}_{2}$. The total $\mathrm{CO}_{2}$ produced by low-ranked coal burning is 103.8 tonnes/hour, while hybrid coal burning produces 96.54 tonnes/hour with $18.4 \%$ of $\mathrm{CO}_{2}$ emmited being neutral. Therefore, the selling price of hybrid coal product is set at USD 80/tonne or IDR 1,124,000/tonne and the coal utilization comparison results are presented in Table 9.

Table 9. Comparison of the use of lignite coal and hybrid coal in power plant.

\begin{tabular}{lcc}
\hline \multicolumn{1}{c}{ Parameter } & Low Ranked Coal & Hybrid Coal \\
\hline Coal Demand & 350,285 TPY & 249,308 TPY \\
Coal Price (annually) & IDR 255.9 Billion & IDR 280.2 Billion \\
Carbon Tax (annually) & IDR 115.5 Billion & IDR 87.7 Billion \\
\hline
\end{tabular}

Based on Table 9, although the cost of purchasing the hybrid coal is almost IDR 25 billion/year higher than the low-ranked coal, the carbon tax paid is lower by almost IDR 28 billion/year, making it an annual savings of $13 \%$. Economic analysis and calculation of economic parameters are carried out using discounted cumulative cashflow analysis for hybrid coal plants in each area referring to Turton's textbook (Turton et al., 2012). Economic parameters that are important to find out when analyzing project feasibility are payback period, net present value (NPV) and internal rate of return (IRR). Based on this analysis, the net profit from hybrid coal plants is in the range of IDR 137 billion to IDR 495 billion annually. Further details regarding forementioned economic parameters are presented in Table 10.

Table 10. Hybrid coal plant economic parameters.

\begin{tabular}{lccc}
\hline \multirow{2}{*}{ Plant Area } & \multicolumn{3}{c}{ Economic Parameter } \\
\cline { 2 - 4 } & Payback Period & NPV & IRR \\
\hline Central Java & 10.5 years & IDR $1,107,221,794,028$ & $15.9 \%$ \\
South Kalimantan & 13.2 years & IDR $285,767,582,175$ & $13.2 \%$ \\
South Sumatera & 10.2 years & IDR $312,404,755,148$ & $16.0 \%$ \\
\hline
\end{tabular}

Based on the economic parameters in Table 10, it is known that the time required to recover the capital costs for the construction of hybrid coal plant is in the range of 10-13 years after the plant start-up period. This figure is still within the typical range for the construction of a chemical process industry, which is in the 7-13 year range (Turton et al., 2012). In terms of cash position, this project is already profitable since the NPV is not negative and has a large value ranging from IDR 285 billion to IDR 1.1 
trillion. Lastly, in terms of interest rate criteria, the IRR of the project has promising value and is categorized as economically feasible project which sufficiently reasonable to be funded. The average WACC of the national banking system is $7 \%$, while the average deposit interest rate is $9 \%$. Therefore, the internal rate of return by investing funds in this project can be considered very profitable since it is able to provide higher interest than the bank WACC and deposits. The approximate discounted cumulative cashflow diagram for the hybrid coal plant project is depicted in Figure 11.

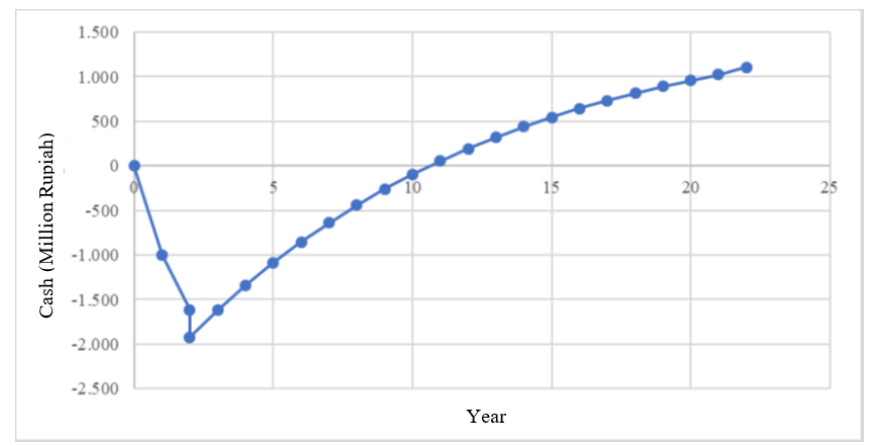

Figure 11. Hybrid coal plant project discounted cumulative cashflow.

\section{Conclusion}

The utilization of Indonesian potential energy sources that are extremely abundant such coal reserves (especially low-ranked coal with a potential of 39.56 billion tonnes) and biomass waste (32.6 GW potential) is necessary in order to achieve energy security and fulfill the increasing energy demand in Indonesia. Hybrid coal product innovation might be a solution to optimize existing energy source while solving biomass waste problem in Indonesia. Hybrid coal can be produced by combining lignite coal with biomass waste such rice husks, empty fruit bunches and rubber wood with a ratio of coal to biomass of 7:3. The process used is the co-pyrolysis process which increases the calorific value of coal and biomass mixture by $31.10-44.12 \%$ and reduces non-neutral $\mathrm{CO}_{2}$ emissions by $15.56-21.31 \%$ compared to its constituent coal, making it more environmentally friendly source of energy. In the industrial scale production of hybrid coal, there are 3 prospective locations to build hybrid coal plants: Central Java, South Sumatra and South Kalimantan. Economic analysis of hybrid coal industry project with production capacities of 540 thousand to 4.5 million TPY produces payback period of 10-13 years with a profit range of IDR 137 billion to IDR 493 billion per year and a net present value range of IDR 285 billion to IDR 1.1 trillion. This industry is also profitable for investors by providing IRR estimation range of $13.2 \%$ to $16.0 \%$. In addition, hybrid coal products also provide benefits for users like power plants in the form of annual savings of $13 \%$ when the carbon tax policy is implemented. Through various experimental research and analysis of the hybrid coal production and its industrial feasibility, hybrid coal is the current most promising and prospective innovation in all economical, qualitative and environmental manner. It is believed to be a reliable source to achieve energy security in Indonesia.

\section{Abbreviations}

$\begin{array}{ll}\text { AGM } & =\text { Antang Gunung Meratus } \\ \text { BA } & =\text { Bukit Asam } \\ \text { C } & =\text { Carbon element content } \\ \text { CPO } & =\text { Crude Palm Oil } \\ \text { GCV } & =\text { Gross Calorific Value } \\ \text { GDP } & =\text { Gross Domestic Product } \\ \text { GHG } & =\text { Greenhouse Gases } \\ \text { GW } & =\text { Giga Watt } \\ \text { H } & =\text { Hydrogen element content } \\ \text { IRR } & =\text { Internal Rate of Return } \\ \text { kWh } & =\text { kilo Watt hour } \\ \text { MTOE } & =\text { Million Tonnes of Oil Equivalent }\end{array}$

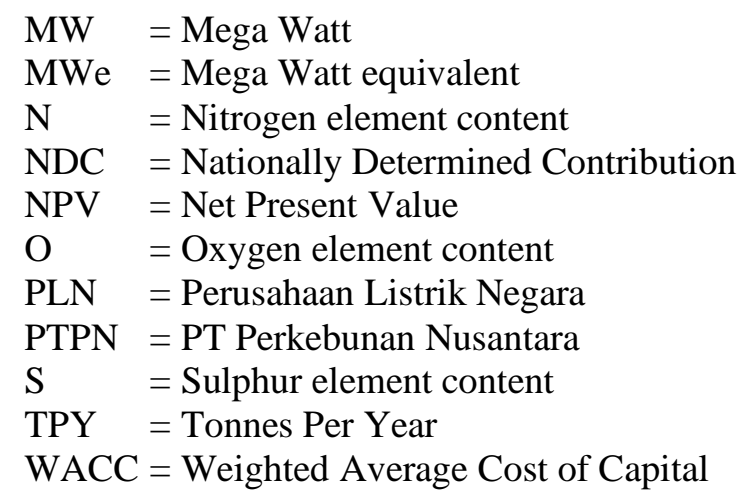




\section{References}

Basu, P. (2013). Biomass gasification, pyrolysis and torrefaction: Practical design and theory. Biomass Gasification, Pyrolysis and Torrefaction: Practical Design and Theory. https://doi.org/10.1016/C2011-0-07564-6

BPPT. (2018). Indonesia energy outlook 2018: Sustainable energy for land transportation. Agency for The Assessment and Application of Technology (Vol. 134).

Direktorat Jenderal Mineral dan Batubara. (2020). Laporan kinerja tahun 2020.

Ditjen EBTKE. (2016). Statistik EBTKE 2016.

Gielen, D., Saygin, D., \& Rigter, J. (2017). Renewable energy prospects: Indonesia. International Renewable Energy Agency (IRENA). https://doi.org/10.1145/347642.347800

Kementerian Energi dan Sumber Daya Mineral. (2016). Data inventory emisi GRK sektor energi. https://www.esdm.go.id/assets/media/content/content-data-inventory-emisi-grk-sektor-energi.pdf

Kementerian Energi dan Sumber Daya Mineral. (2017). Kajian penggunaan faktor emisi lokal (Tier 2) dalam kajian inventarisasi GRK sektor energi.

Kementerian Energi dan Sumber Daya Mineral. (2020). Laporan kinerja Kementerian ESDM 2020.

Kementerian Pertanian. (2018). Agricultural Statistics 2018.

PT. PLN (Persero). (2018). Annual report 2018.

PT. PLN (Persero). (2019). Electric power supply business plan (2019-2028). http://gatrik.esdm.go.id/assets/uploads/download_index/files/5b16d-kepmen-esdm-no.-39-k-20mem-2019-tentang-pengesahan-ruptl-pt-pln-2019-2028.pdf

Quan, C., \& Gao, N. (2016). Copyrolysis of biomass and coal: A review of fffects of copyrolysis parameters, product properties, and synergistic mechanisms. BioMed Research International, 2016. https://doi.org/10.1155/2016/6197867

Roni, M. S., Chowdhury, S., Mamun, S., Marufuzzaman, M., Lein, W., \& Johnson, S. (2017). Biomass co-firing technology with policies, challenges, and opportunities: A global review. Renewable and Sustainable Energy Reviews, 78(May), 1089-1101. https://doi.org/10.1016/j.rser.2017.05.023

Sasongko, D., Wulandari, W., Rubani, I. S., \& Rusydiansyah, R. (2017). Effects of biomass type, blend composition, and co-pyrolysis temperature on hybrid coal quality. AIP Conference Proceedings, 1805, 2-8. https://doi.org/10.1063/1.4974430

Song, Y., Tahmasebi, A., \& Yu, J. (2014). Co-pyrolysis of pine sawdust and Lignite in a thermogravimetric analyzer and a fixed-bed reactor. Bioresource Technology, 174, 204-211. https://doi.org/10.1016/j.biortech.2014.10.027

Suharyati, Pambudi, S. H., Wibowo, J. L., \& Pratiwi, N. I. (2019). Indonesia energy outlook 2019 (Vol. 1). https://doi.org/ISSN 2527-3000

Tun, M. M., Juchelkova, D., Win, M. M., Thu, A. M., \& Puchor, T. (2019). Biomass energy: An overview of biomass sources, energy potential, and management in Southeast Asian countries. Resources, 8(2). https://doi.org/10.3390/resources8020081

Turton, R., Bailie, R. C., Whiting, W. B., Shaeiwitz, J. A., \& Bhattacharyya, D. (2012). Analysis, synthesis, and design of chemical processes. Pearson Education, Inc. (4th ed.). https://doi.org/10.5860/choice.36-0974 